\title{
GHANAIAN INDIGENOUS CONCEPTION OF REAL MATHEMATICS EDUCATION IN TEACHING AND LEARNING OF MATHEMATICS
}

\author{
Clement Ayarebilla Ali
}

Department of Basic Education, Faculty of Educational Studies, University of Education, Winneba, Ghana

Corresponding author: acali@uew.edu.gh

\begin{tabular}{l}
\hline \hline Article Info \\
\hline Article history:
\end{tabular}

Received: October 30, 2020

Accepted: March 27, 2021

Published: March 31, 2021

Keywords:
Four trends of mathematisation
Indigenous conception
Real mathematics education
Teaching and learning of
mathematics

\begin{abstract}
Ghana abounds in indigenous resources but little mathematics has been conceptualised. The study therefore applied the four trends of real mathematics education on five main Ghanaian indigenous materials. The design was quasi-experimental non-equivalent groups of experimental (80) and control (70) students. The experimental group was taught with the four trends and the control with the traditional approach. The researcher used teacher-made test instruments through the standard psychometric techniques and tagged them as pretest and post-test scores. Both tests were similar and given to both groups before and after the treatments. The results show that the main indigenous Ghanaian materials were signs/symbols, artefacts, instruments, tools and technologies, and signs/symbols being the most significant. These results were then applied to the teaching and learning of mathematics at the senior high school levels. The researcher therefore recommends that students should be allowed to use indigenous mathematical ideas, concepts, generalizations and thoughts processes
\end{abstract}

\begin{tabular}{|c|c|}
\hline \multicolumn{2}{|c|}{$\begin{array}{l}\text { KONSEP BUDAYA MASYARAKAT GHANA PADA } \\
\text { MATEMATIKA MURNI DALAM PENGAJARAN DAN } \\
\text { PEMBELAJARAN MATEMATIKA }\end{array}$} \\
\hline & ABSTRAK \\
\hline $\begin{array}{l}\text { Kata Kunci: } \\
\text { Four trends of mathematisation } \\
\text { Konsep budaya } \\
\text { Pengajaran matematika murni } \\
\text { Pembelajaran matematika }\end{array}$ & $\begin{array}{l}\text { Negara Ghana dilimpahi dengan kebudayaan, tetapi sedikit konsep } \\
\text { matematika yang telah dimanfaatkan untuk hal ini. Oleh karena itu, } \\
\text { penelitian ini menerapkan empat tren pendidikan matematika pada } \\
\text { lima kebudayaan utama bagi penduduk asli Ghana. Desain } \\
\text { penelitian yang digunakan adalah kuasi eksperimental non- } \\
\text { ekuivalen, dengan kelompok eksperimental sejumlah (80) dan } \\
\text { kelompok kontrol sejumlah (70) siswa. Kelas eksperimen diajar } \\
\text { dengan four trends of real mathematics dan kelas kontrol dengan } \\
\text { pendekatan tradisional. Peneliti menggunakan instrumen tes buatan } \\
\text { guru melalui teknik psikometri standar untuk mendapatkan nilai } \\
\text { pretes dan postes. Kedua tes tersebut serupa dan diberikan kepada } \\
\text { kedua kedua kelas pada sebelum dan sesudah perlakuan. Hasil } \\
\text { penelitian menunjukkan bahwa kebudayaan utama asli Ghana } \\
\text { adalah tanda/simbol, artefak, instrumen, alat dan teknologi, dan } \\
\text { tanda/simbol adalah yang paling signifikan. Hasil ini kemudian } \\
\text { diterapkan pada proses belajar mengajar matematika di tingkat } \\
\text { SMA. Oleh karena itu, peneliti merekomendasikan agar siswa } \\
\text { diperbolehkan menggunakan ide, konsep, generalisasi, dan proses } \\
\text { pemikiran matematika asli. }\end{array}$ \\
\hline
\end{tabular}




\section{INTRODUCTION}

There has been significant amount of research in indigenous learning of mathematics. Some of the authors concentrated on indigenous students and the learning of mathematics [1], an exploration into mathematical concepts embedded in the everyday activities of indigenous knowledge holders [2], mathematics remediation for indigenous students with learning difficulties [3], accelerated indigenous mathematics [4], and culturebased school mathematics for reconciliation and professional development [5]. In most of the research the concept of variety of indigenous materials expected to be used for teaching and learning mathematics have not been well bridged.

Ghana and many developing countries have indigenous resources that could be explored to teach mathematics. However, little literature has been conceptualised, concretised and indigenised mathematical conceptions. And even though indigenous Ghanaian technologies exist in designs of weaving, blacksmith and textiles, not much attention is paid to the mathematically-rich emblems, decorations and ornamentals $[6,7]$. The main Ghanaian indigenous materials one can find from these designs are signs/symbols, artefacts, tools, instruments and technologies [8, 9]. However, the little attention and disinterest in literature widens the gaps between home and school mathematics knowledge, instruction, relationships and achievements [10]. Research by [11] has shown that indigenous conception of materials in teaching and learning of mathematics demystifies the rule-bound routines, structural algorithms and rote learning. It gives students the opportunity to realistically do mathematical thinking and operations.

RME is a domain-specific teaching, learning and instruction theory that provides rich realistic situations and contexts in the teaching and learning processes. The theory holds the view that mathematics must be connected to reality [12] in other to serve as sources to the development of mathematical concepts, tasks, procedures and contexts [13]. In this theory, [14] argues that students offer a variety of problem situations to explore and construct knowledge from the real-world situations with either fantasy fairy tales or formal world of mathematics, so long as the problems are experientially real. Even though the socio-constructivist dimensions embedded in RME provides compatible and complementary collaborations, critical roles of classroom cultures and mathematics discourses [15], many mathematics educators and students have not been able to successfully transition the four RME-interrelated approaches into one realistic mathematics discourse $[16,17]$ with the following model.

Table 1. Model of Horizontal and Vertical Mathematisation in Four Different Mathematics Education Trends [17]

\begin{tabular}{ccc}
\hline \multirow{2}{*}{ Trend } & \multicolumn{2}{c}{ Mathematizing } \\
\cline { 2 - 3 } & Horizontal & Vertical \\
\hline Mechanistic & Absent & Absent \\
Empiricist & Present & Absent \\
Structuralist & Absent & Present \\
Realistic & Present & Present \\
\hline
\end{tabular}

On Table 1, the mechanistic (or arithmetic) trend shows that no real phenomenon is being used as a source of mathematical activity, little attention is being paid to applications and the emphasis is on rote learning. This results in weaknesses (absences) in both horizontal and vertical mathematisation. The empiricist trend places a strong emphasis on horizontal mathematisation in that the emphasis is on social/environmental/cultural rather than on mental operations. Formal mathematical goals do not feature as a high priority and there is little pressure for learners to pass to a higher level, thus demonstrating the weakness with relation to vertical mathematisation. In structuralist instruction, where mathematical structures are emphasised, the vertical component is dominant. This is evident in this 
approach in that the principal part of the mathematical activity operates within the mathematical system. Instead of real phenomena, embodiments and materialisations of mathematical concepts or structures or structural games, plays and fun are used to create a concrete basis for learners from which to work and real phenomena subsequently do not function as models to support operating within the mathematical system.

In realistic mathematics instruction, however, careful attention is being paid to both components [17]. This means that the phenomena from which the mathematical concepts and structures arise are implicitly used both as source and domain of application. This creates for the learner the possibility of concept attainment by orienting himself to a variety of phenomena, which benefits the building of formal mathematical concepts and structures and their applications. It therefore appears that a lot of the teaching and learning in this domain has intended towards the mechanistic (arithmetic) and structuralist trends. The focus of the instruction and assessment has therefore been in the vertical component of Table 1, which could explain the dominance of instrumental rather than relational understanding $[17,18]$.

Also, the integrated four trends shows that teaching and learning of mathematics progress from horizontal mathematization (i.e. transfer of real world problems to mathematically stated problems, and/or from the world of life to the world of signs and symbols to act). Concurrently, vertical mathematization as a form symbiosis shapes, reshapes and manipulates the indigenous signs, symbols, artefacts and tools in other to improve teaching and learning [19]. The mechanistic phase sets up the systems of logic, deductions, rules and formulas in Equations of the Circle, the empiricist sets up applications, methodologies, structures, interrelations and insights, the structuralist organizes logical, closed deductive, procedural and algorithmic procedures to prepare classroom instruction for real mathematics encounters, and the realistic phase incorporates indigenous materials into classroom instruction [20].

This study therefore sought to answer the questions of what mathematics knowledge can students find from the Ghanaian indigenous materials, how students will derive mathematics knowledge from the main indigenous Ghanaian materials and which one(s) is the most significant for teaching and learning mathematics. Also, the study seeks to answer the questions of how students can perform using the main indigenous Ghanaian materials to solve mathematics problems. It is hoped that the students will not only perform well and obtain high achievement in mathematics but also value the indigenous materials in the context of teaching and learning mathematics in the formal setting [21, 22].

\section{METHOD}

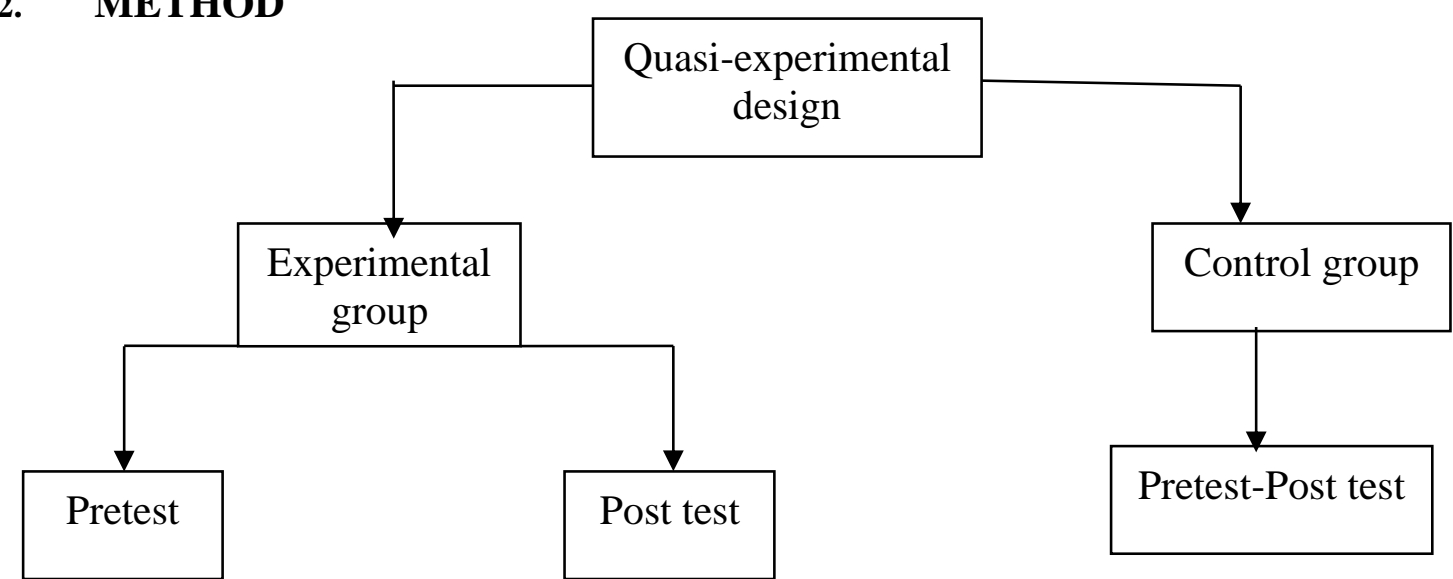

Figure 1. A Flow Chart of an Experimental Design Process 
Figure 1 describes the flow chart of the quasi-experimental non-equivalent group design. The study sample involved 150 out of 300 mathematics students of Navrongo Senior High School in Ghana. The sample was divided into experimental (80) and control (70) groups, where RME and traditional approaches were used respectively. The experimental group composed of 65 male and 15 female students, while the control group had 55 male and 15 female students. Both groups contained a mixture of low ability, average ability and high ability. These mathematics abilities were based on the results of their mathematics achievements in the second year. The control group was then created for comparison with the experimental group [23].

The design also describes an experiment that consisted of units with treatments. This approach was utilised because the study used the existing class, who were not selected randomly. The quasi-experimental design was used to determine the effectiveness of the RME approach in improving teaching and learning of mathematics, using indigenous materials. Pretest and post test were conducted in both groups. The pretest ensured similarity between groups and statistical control by comparing the mean of signs, symbols, artefacts, tools, instruments and technologies in solving mathematics problems with significant value of more than 0.05 . The experimental group was given tasks using the RME approach in teaching, whereas the traditional method was used as control group [24]. Students in both groups were taught for one week in their respective classrooms. The posttest was given to both groups after they were taught selected topics in equations of the circle to determine the effectiveness of the RME approach [25]. The test questions for preand post-tests were similar. The researcher observed each session for both groups throughout the discussion [26].

Two teachers were involved in the RME approach based on their experiences in teaching elective mathematics in the school. The teachers underwent training for one week to ensure the success of the study and consistency with the design plan. The study objectives, RME and traditional approaches, planning and execution process and assessment methods were introduced to the teachers. The same teachers were assigned to treatment and control groups. The study was conducted after they understood the entire concept. The researcher observed throughout the study to determine whether the teachers were using the RME approach. Observation began from the start until the end of class for every session. The teachers were given feedback about their teaching. The researcher observed the traditional class to ensure that the teachers were not using the RME approach or any other related teaching method [26].

In the experimental group, the teachers followed four main phases to teach this approach. In the first phase, teachers introduced realistic problems to students and helped them understand the problem setting [27]. Teachers revised previous concepts and connected them with the experience of students. In the second phase, students worked in groups. Each student had a book that contained contextual questions and constructed situational problems, shared ideas, analyzed patterns, made guesses and expanded problem-solving strategies based on knowledge or formal experience. The third phase of assessment showed the progress of students in problem solving. They discussed their problems and discovered useful strategies. The fourth phase, teachers asked students recall their facts, generalizations and formulae they have discovered in the activities. In all these phases, teachers guided and instructed students throughout the discussions on how to solve the problems efficiently and effectively [28, 29].

In the control group, students were taught using a marker and whiteboard. They participated in the exercises given by the teachers. The exercises were based on the textbooks provided by the school. Teachers narrated and jotted down information on the 
whiteboard. The enhanced educational curriculum unit requires every teaching method to be contextual. Thereafter observations were conducted for 5 weeks in 10 sessions for both groups. Internal and external validities were determined [23].

Internal validity is a controlled variable set by the researcher that aims to identify the actual effect on the treatment variable. External validity sees how far the findings can be applied to individuals and settings other than the ones in the study. Issues of selection of research and lost subjects (mortality), emotional maturity, intellectual and physical wellbeing, testing, research instrument and validity of research objects, can arise from the quasi-experimental designs. These issues related to the study and the attitude and emotion of students [21].

In the data analysis with analysis of variance (ANOVA) [27], it was performed to identify the difference in indigenous materials between the treatment and the control groups. In cases of no or small statistical significance, an analysis of covariance (ANCOVA) was added, where gender and/or programme served as covariates, to statistically control error variances. This step was followed up by multivariate analysis to confirm the statistical effects of the interactions [20].

\section{RESULTS AND DISCUSSION}

It must be re-emphasized that two groups of treatments i.e. experimental and control were used for the data. In the experimental treatment, the results were based on the main indigenous materials obtained from the data. In the control treatment, the results were used during the pretest to remove internal threats to validity of the experimentation processes. Since there was no apparent intention to report and anlayse the results of the control group, there were quarantined in the experimental group [23, 27].

In the results and discussion, two parts have been outlined in two sections. The first section describes the results on tables 3.1 and 3.2. Table 3.1 describes simple one-way ANOVA of the main Ghanaian indigenous mathematics materials. These materials were derived from the environment of the participants from a checklist of many materials around the participants' immediate endowment. A material that received over 50\% endorsement of the participants were worthy of inclusion on this table. If less than $50 \%$ of the research participants did not select it, it was set aside and considered non-indigenous for the purpose of this research. Table 3.2 describes the effect of gender and programmes that students pursue in order to assess the impact of the indigenous materials. Because Ghanaian students who study mathematics are still dominated by male students, it was imperative that we assessed gender [24]. And because the values of mathematics in Ghana are determined by the programmes students pursue, it was equally important that we factor programme into the analysis [26]. The second section describes in details the findings of the research in relation to literature. The discussions were derived according to the two research questions. There were really meant to confirm or refute the findings with other literature. By so doing, concrete and fundamental recommendations could be subsequently arrived at in order to inform policy.

Research Question 1: What mathematics knowledge can students find from the Ghanaian indigenous materials, how students will derive mathematics knowledge from the main indigenous Ghanaian materials and which one(s) is the most significant for teaching and learning mathematics.

The researcher used ANOVA statistics to explore this question. These variables were the main Ghanaian indigenous materials. The indigenous materials on Table 2 best determined the interactions in RME in solving mathematics problems. 
Table 2. What, How and Most Ghanaian Indigenous Materials in Mathematisation

\begin{tabular}{|c|c|c|c|c|c|c|c|}
\hline Components & & Sum of Squares & Df & Mean Square & $\mathbf{F}$ & Sig. & Eta squared \\
\hline \multirow[t]{3}{*}{ Signs/Symbols } & Between & 43.870 & 4 & 10.968 & 7.653 & .000 & .06 \\
\hline & Within & 703.614 & 76 & 1.433 & & & \\
\hline & Total & 747.484 & 80 & & & & \\
\hline \multirow[t]{3}{*}{ Artefacts } & Between & 3.605 & 4 & .901 & .554 & .696 & .004 \\
\hline & Within & 798.554 & 76 & 1.626 & & & \\
\hline & Total & 802.159 & 80 & & & & \\
\hline \multirow[t]{3}{*}{ Instruments } & Between & 25.209 & 4 & 6.302 & 3.888 & .004 & .03 \\
\hline & Within & 795.816 & 76 & 1.621 & & & \\
\hline & Total & 821.024 & 80 & & & & \\
\hline \multirow[t]{3}{*}{ Tools } & Between & 34.154 & 4 & 8.539 & 4.814 & .001 & .04 \\
\hline & Within & 870.957 & 76 & 1.774 & & & \\
\hline & Total & 905.111 & 80 & & & & \\
\hline \multirow[t]{3}{*}{ Technologies } & Between & 15.365 & 4 & 3.841 & 1.860 & .116 & .01 \\
\hline & Within & 1013.875 & 76 & 2.065 & & & \\
\hline & Total & 1029.240 & 80 & & & & \\
\hline
\end{tabular}

On Table 2, the main indigenous Ghanaian materials are signs/symbols, artefacts, instruments, tools and technologies. The one-way between-groups ANOVA show that there were statistically significant differences at the $(p<.05)$ in Ghanaian indigenous signs/symbols, instruments and tools. However, signs/symbols were the most significant indigenous Ghanaian materials. Despite the three reaching statistical significance, the actual difference in mean scores between the groups were quite small. The effect size, calculated using eta squared, ranged between .004 to .06. However, there were no significant differences in artefacts and technologies. The mean scores did not differ significantly among all the groups in artefacts and technologies. Therefore, there were little interactions in the four trends with respect to artefacts and technologies.

It is worthy to note that after adjusting for gender differences, there were statistically significant differences $[\mathrm{p}=.016$, partial eta square $=.021]$. Because students were not randomly assigned to the groups, confounding gender only significantly reduced the differences of group means. Also, the partial eta squared coefficients described how much of the variances in the four trends of mathematisation were explained by the significant phases. The small partial eta squared values revealed that there were no strong relationships between the four trends. However, estimated marginal adjusted the mean scores statistically removed these effects by 1.49 .

Research Question 2: How do students perform in using the main indigenous Ghanaian materials to solve mathematics problems?

The researcher used MANCOVA statistics to explore this question. The analysis can be seen in Table 3.

Table 3. MANCOVA Tests in all Four Phases of RME

\begin{tabular}{llcccccc}
\hline & Effect & Value & F & Hypothesis df & Error df & Sig. & $\begin{array}{c}\text { Partial Eta } \\
\text { Squared }\end{array}$ \\
\hline \multirow{2}{*}{ Intercept } & Wilks; Lambda & .855 & $6.835^{\mathrm{a}}$ & 3.000 & 60.000 & .000 & .145 \\
& Roy's Largest Root & .169 & $6.835^{\mathrm{a}}$ & 3.000 & 60.000 & .000 & .145 \\
Gender & Wilks' Lambda & .944 & $3.310^{\mathrm{a}}$ & 3.000 & 60.000 & .000 & .056 \\
& Roy's Largest Root & .059 & $3.310^{\mathrm{a}}$ & 3.000 & 60.000 & .000 & .056 \\
\hline
\end{tabular}




\begin{tabular}{llcccccc}
\hline Programme & Wilks' Lambda & .993 & $0.047^{\mathrm{a}}$ & 3.000 & 60.000 & .371 & .007 \\
& Roy's Largest Root & .007 & $0.047^{\mathrm{a}}$ & 3.000 & 60.000 & .371 & .007 \\
Signs/symbols & Wilks' lambda & .917 & 1.478 & 12.000 & $0.257 \mathrm{E} 3$ & .000 & .028 \\
& Roy's Largest Root & .061 & $2.317^{\mathrm{b}}$ & 4.000 & 62.000 & .000 & .058 \\
Artefacts & Wilks' Lambda & .976 & .753 & 12.000 & $0.257 \mathrm{E} 3$ & .492 & .008 \\
Instruments & Wilks' Lambda & .974 & 0.293 & 9.000 & $0.156 \mathrm{E} 3$ & .186 & .009 \\
& Roy's Largest Root & .019 & $0.948^{\mathrm{b}}$ & 3.000 & 62.000 & .032 & .018 \\
\multirow{2}{*}{ Technologies } & Wilks' Lambda & .981 & .455 & 12.000 & $0.431 \mathrm{E} 3$ & .698 & .006 \\
& Roy's Largest Root & .011 & $0.250^{\mathrm{b}}$ & 4.000 & 62.000 & .250 & .011 \\
\hline
\end{tabular}

On Table 3, students' gender and programme were held as the covariates. After adjusting for the two covariates, there were significantly statistical differences in signs/symbols and instruments but signs/symbols remained the most significant indigenous Ghanaian materials. However, even though the multivariate partial eta squared values showed small effects, the results of the estimated marginal means statistically controlled the effects. To further confirm the significant effects of the RME models, the Wilks' lambda shows that $1 \%$ increase in the RME increased the rate of interactions by $0.917 \%, 0.976 \%, 0.974$ and 0.981 respectively. So there really positive significant effects of RME models in using the Ghanaian indigenous materials to solve problems in mathematics.

In the interactions, students steadily migrated across the four phases of realistic mathematics education. In the one-way between-groups ANOVA, the students' knowledge before the implementation of the RME model was quite limited. However, as the students progressed from one level of interaction to another, they became quite proficient and efficient $[17,18]$. This explains why they achieved the statistically significance across four phases. Despite reaching statistical significance, the actual differences in mean scores were quite small as supported by the effect sizes through eta squared values and Tukey HSD test [11]. However, the mean scores did not differ significantly in artefacts and technologies. This was traced to the exclusion of the technologies. The results show that the RME approach is much superior [22].

The results show that the mechanistic approach mathematics did give students a system of rules to verify and apply on the mathematics problems [14]. However, there were inadequate involvement not only in the application and methodology but also structure, interrelatedness and insight about how the Ghanaian indigenous tools should be used [15]. So, we could readily observe that both horizontal mathematization and vertical mathematization were weak in this approach [14]. The structuralist trend considered mathematics as being closed deductive system [15]. This explains why students emphasised the mathematical structures in the four phases of the MANCOVA.

However, the vertical mathematization was stressed excessively, whereas attention to horizontal mathematization was insufficient [14]. The empiricist trend mainly helped students to gather indigenous Ghanaian teaching and learning materials to acquire useful experiences $[15,16]$. However, but they were not prompted to systematise and rationalise these experiences in order to break the barriers of the environment and to expand their knowledge to socio-cultural reality [14]. But for not detecting gender and programme of students in the ANCOVA and MANCOVA [24], the results would have been so abysmal and catastrophic. 
Upon true and proper interpretation of indigenous Ghanaian mathematics materials, it was discovered that students cannot bring the reality into the classroom without identifying not plausible and effective indigenous materials but also well-chosen contextual mathematics problems [17]. The trend model brought variety and differences into students' knowledge of applying indigenous Ghanaian materials to solve mathematics problems. It enables students to not only value their cultural artefacts [10] but also value their mathematical heritage [21].

To sum up, a semiotic chain in the use of different indigenous materials, from signs to technology tools were discovered and consolidated $[4,5,22]$. The students started with simple local signs and symbols of mathematics inclinations to more complex technology tools of international integrative cultures. In doing so, the concept of indigenisation was much extended in the concept of mathematics instruction rather than a concept of localisation of materials. However, what became clear is that indigenous materials originated from students' immediate environment and were extended to much wider cultures.

\section{CONCLUSION}

The findings showed that the utilization of the RME models provided new mathematical concepts, structures and ideas in relation to the phenomena and contexts. In learning and solving tasks, students successfully applied, explained and related a variety of signs, symbols, artefacts and tools. Particular engagements with the Ghanaian indigenous materials were sustainable in Vygotsky's socio-cultural tools.

We can therefore infer that the mechanistic dialogue provided the indigenous materials, the structuralist dialogue provided deductive and generalizations of the uses of the indigenous materials, the empiricist dialogue provided actual classroom applications and utilizations of the indigenous materials, and the realistic dialogue provided comprehensive RME phenomenology of their applications in daily real life situations.

Following the above, it was concluded that the indigenous materials have a strong link with students' mathematics achievements and performance. The use of different well hierarchical orchestrated indigenous materials helped students to articulate the different concepts. In the experiment, it was realised that the main achievement was the students' use of the signs and symbols. Because they knew know how to use them, they were able to master the use of the technology tools in advanced forms.

Following these innovative and thought-provoking findings, the researcher recommends that indigenous materials be used to enhance the development of real mathematics education. Students should be allowed to use any indigenous mathematical ideas, concepts, generalizations and thought processes in learning mathematics. In addition, students should be afforded an opportunity to actually do mathematics based on local construct and resources by using the indigenous materials. Gender and programmes of study should be focal points of using indigenous materials in mathematics instruction.

Furthermore, the use of indigenous Ghanaian materials in teaching and learning mathematics makes the teaching and learning of mathematics less of a rule bound routine and more of engaging in real-life local situations. The researcher therefore recommended many more indigenous and local resources should be rediscovered and redesigned to suit all areas of mathematics..

Lastly, the findings show that teachers and students were both equally placed to indigenize mathematics experiences inside and outside the classroom. It was recommended that teachers should improvise indigenous mathematics materials to bridge the yawning 
gaps between home and school mathematics, and narrow the gaps between horizontal and vertical mathematisation.

\section{AKNOWLEDGMENT}

I thank the Regional Director of Education of the Upper East Region, and Head Mistress and Management of Navrongo Senior High School who provided insight and expertise that greatly assisted the research, although they may not agree with all of the interpretations and conclusions of this paper.

I also thank Mr. Yaro Abuntuick, the Head of Department of Mathematics, Staff and students of mathematics for their active participation in the research that greatly improved the manuscript.

\section{REFERENCES}

[1] T. Meaney, C. McMurchy-Pilkington and T. Trinick, "Indigenous Students and the Learning of Mathematics", Research in Mathematics Education in Australasia 2008-2011 pp 67-87, 2012.

[2] T.G. Bartell, K.N. Bieda, R.T. Putnam, K. Bradfield and H. Dominguez (Eds.), Indigenous Knowledge Provides an Elegant Way to Teach the Foundations of Mathematics. Proceedings of the $37^{\text {th }}$ annual meeting of the North American Chapter of the International Group for the Psychology of Mathematics Education. East Lansing, MI: Michigan State University, 2015.

[3] P.C. Yong, Y.K. Jiar and N.A.A. Zanzali, "Mathematics Remediation for Indigenous Students With Learning Difficulties: Does It Work?'.US-China Education Review A, 1022-1033, 2012.

[4] YuMi Deadly Centre, Accelerated Indigenous Mathematics, Commonwealth of Australia, YuMi Deadly Centre, Queensland University of Technology, 2014.

[5] K. Duchscherer, S. Palmer, K. Shemrock and D. Vankoughnett, "Culture-Based School Mathematics for Reconciliation and Professional Development".Indigenous Culture-Based School Mathematics: Project Report 287, July 2019.

[6] R. Wemegah, "Boosting the Bolgatanga Basketry Industry: Inputs from the IndiaAfrica Craft Design Initiative", International Journal of Innovation and Applied Studies, 9(2), 897-905, 2014.

[7] D. Tall, How humans learn to think mathematically, Cambridge: Cambridge University Press, 2013.

[8] C.A. Ali, E.K. Davis and D.D. Agyei, D.D.,"Transition from Instrumental Genesis to Anthropological Theory of Didactics in the Teaching and Learning of Mathematics in Basic Schools". In Pope, S. (Ed.). British Congress of Mathematics Education (pp.30- 34),University of Warwick, United Kingdom, March 2018.

[9] L. S. Vygotsky, Tool and sign in the development of the child. In R. W. Rieber (ed.), The collected works of L. S. Vygotsky, Volume 6 (pp. 3-68). New York: Kluwer Academic, 1999.

[10] C.A. Ali, "Harnessing Indigenous Basketry Resources for Prenumber and Early Number Work" Journal of Education and Learning, 7(2), 210-220, June 2018.

[11] H. Freudenthal, Didactical Phenomenology of Mathematical Structures. Dordrecht: Riedel Publishing Company, 1983.

[12] E. Matusov, “Irreconcilable differences in Vygotsky's and Bakhtin's approaches to the social and the individual: an educational perspective",Culture \& Psychology,17(1), 99- 119, 2011. 
[13] M. Van den Heuvel-Panhuizen, P. Drijvers, M. DoormanandM. Van Zanten, Reflections from abroad on the Netherlands didactic tradition in mathematics education. $\quad$ Freudenthal Institute, Utrecht University, Utrecht, 2016.

[14] A. Fauzan, Applying realistic mathematics education (RME) in teaching geometry in Indonesian primary schools, $\mathrm{PhD}$ Dissertation, University of Twente, Enschede, Netherlands, 2002.

[15] A.J. Bishop, H. Bauersfeld, B.J. Kilpatrick, G. Leder, S. T., Krakow and G. Vergnaud. G. (eds.). Revisiting Mathematics Education: China Lectures. Dordrecht: Kluwer Academic Publishers, 2002.

[16] E. K. Davis and S. Chaiklin, S.“A radical-local approach to bringing cultural practices into mathematics teaching in Ghanaian primary schools, exemplified in the case of measurement". African Journal of Educational Studies in Mathematics and Sciences, $11,2015$.

[17] H. Barnes, "The theory of Realistic Mathematics Education as a theoretical framework for teaching low attainers in mathematics",Pythagoras 61 (1),42-57, 2005.

[18] L.T. Anh, Applying Realistic Mathematics Education in Vietnam: Teaching middle school geometry, $\mathrm{PhD}$ Dissertation InstitutfürMathematikLehrstuhlfür, Didaktik der Mathematik, 2006.

[19] M. Van den Heuvel-Panhuizenand P. Drijvers, "Realistic Mathematics Education". In S. Lerman (Ed.), Encyclopedia of Mathematics Education, Dordrecht, Heidelberg, New York, London: Springer, 2011.

[20] M. Turgut, "Theory of semiotic mediation in teaching and learning linear algebra: In search of a viewpoint in the use of ICT". Ninth Congress of the European Society for Research in Mathematics Education (CERME 9), Charles University in Prague, Faculty of Education; ERME, Prague, Czech Republic.pp.2418-2424, Feb 2015.

[21] E. K. Davis, M. E. Carr and E. Ampadu, Valuing in Mathematics Learning Amongst Ghanaian Students: What Does It Look Like Across Grade Levels? In: Clarkson P., Seah W., Pang J. (eds) Values and Valuing in Mathematics Education. ICME-13 Monographs. Springer, Cham, 2019.

[22] W. T. Seah, Values in the mathematics classroom: Supporting cognitive and affective pedagogical ideas. Gazi Journal of Education, 1(1), 45-63, 2013.

[23] J. W. Creswell, Research design: qualitative, quantitative, and mixed methods approach (4ed), Washington DC: SAGE Publications, Inc., 2014.

[24] C. A. Ali, Didactical Conceptual Structures in Extending the Triad to the Tetrahedron Exemplified in the Teaching and Learning of Equations of the Circle, $\mathrm{PhD}$ Thesis, University of Cape Coast, unpublished 2019.

[25] O. Viirman, The function concept and university mathematics teaching. $\quad \mathrm{PhD}$ Dissertation, Karlstad University Studies, Germany, 2014.

[26] J. Ruge and R. Hochmuth, "How do pre-service teachers experience math didactics courses at university?” In Göller, R., Biehler, R., Hochmuth, R., Rück, H.-G. (Eds.), Didactics of Mathematics in Higher Education as a Scientific Discipline - Conference Proceedings, Kassel, Germany: Universitätsbibliothek Kassel, 2017.

[27] D. Subedi, "Explanatory Sequential Mixed Methods Design as the Third Research Community of Knowledge Claim", American Journal of Educational Research, i 4(7), 570-577, 2016.

[28] N. Walliman, Research methods: the basics. New York: Routledge, 2011.

[29] H. J. Seltman, Experimental Design and Analysis, New Delhi: Sage, 2015. 
[30] T. Yu, An exploratory factor analysis and reliability analysis of the student online learning readiness instrument. Online Learning, 19(5), 120-141, 2015.

[31] H. J. Seltman, Experimental design and analysis, New Delhi: Sage, 2015.

[32] B. Caswell, Teaching Toward Equity in Mathematics, PhD Thesis, University of Toronto, 2011. 